\title{
Beyond the current Dutch spatial planning system: towards a beneficial spatial system that accommodates today's complex societal needs
}

\author{
M. Lodder ${ }^{1,2}$, J. Rotmans ${ }^{1}$ \& M. Braungart ${ }^{2}$ \\ ${ }^{I}$ Dutch Research Institute for Transitions (DRIFT), \\ Faculty of Social Sciences, Erasmus University Rotterdam, \\ The Netherlands \\ ${ }^{2}$ Rotterdam School of Management (RSM), Innovation Management, \\ Cradle to Cradle Chair for Innovation and Quality, \\ Erasmus University Rotterdam, The Netherlands
}

\begin{abstract}
This paper will analyse the developments in the spatial planning system in the Netherlands, as of the industrial revolution, as it has led to good practices of international recognition, but now seems to be under pressure because of the increasing complexity and multiple crises induced by societal changes.

This historical analysis will be conducted from a Transition and Cradle to Cradle perspective as the system is optimized, based on technological developments, demographic and economic growth, without integrating the benefits in ecologic and societal values. Various problems as ineffective use of space; loss of ecosystem services in the urbanized areas; and several social problems are the result. In other words, the spatial planning system has multiple system failures and is in need of an alternative perspective.

This alternative perspective will be based on the autonomous developments and recurring patterns. We will highlight how the state, market and civil society could support the generation of ecological and societal benefits through the economic developments in the built environment.

Keywords: spatial planning, urban design, area development, sustainable urban development, sustainable cities, sustainability transitions, transition management, Cradle to Cradle.
\end{abstract}




\section{Introduction}

Since the industrial revolution (western) societies have significantly changed; economic growth increased the levels of comfort, fortune and wealth, while the vitality of the natural environment decreased on the global scale. Since the WCED addressed the issue of sustainability and put in on the international agenda as a challenge for all nations [1], the sustainability challenges in the urban environment received increasing attention. Wealthy nations were to mitigate climate change, limit energy consumption, reduce pollution, protect natural areas and arable land, and provide a safe and healthy environment for citizens in particular the most vulnerable groups [2]. These sustainability challenges resulted, in many European countries, in discussions around the negative environmental consequences of a land consuming urban developments that appeared to converge on the idea of the 'compact city' [3]. This concept has influenced how we design, plan and govern the urban environment.

This paper explores how the relationships between nature and culture in the Netherlands has developed over the past 200, and how the state, market and civil society has reacted upon these developments through urban design concepts and spatial planning policies while placing it into the context of the societal developments.

\subsection{Relevance}

The spatial planning policies of the Netherlands received international recognition (especially in the $20^{\text {th }}$ century), as it has led to good practices, but now seems to be under pressure because of the increasing complexity and multiple crises induced by societal changes. The spatial planning system is optimized, based on technological developments and demographic and economic growth, without integrating benefits for ecologic and societal values. Ineffective use of space; loss of ecosystem services in the urbanized areas; and several social problems are the results from this system. In other words, the spatial planning system has multiple system failures [4] for which this paper aims to offer an alternative perspective by its historical analysis.

\subsection{Methodology and structure}

This paper starts with a historical analysis that will focus on the relation between nature and culture, the technological influences on culture, and the resulting increasing spatial consumption. The paper continues with distilling the recurring patterns that have influenced these autonomous developments with a particular focus on the role of the state, marked and civil society, in order to draw lessons for a beneficial, instead of polluting spatial planning systems including their design and governance. 


\section{Autonomous developments}

\subsection{Relationship between culture and nature}

The Dutch are known for their ability to 'control' nature. Long before the industrial revolution, the fight against water dominated the people living close to the rivers.

\subsubsection{Natural systems as a basis for technology and society}

In the second half of the $19^{\text {th }}$ century, technological innovations and the upcoming natural sciences allowed society to control nature, space and time. The railway system, allowed people to travel, for example, to the mountains and watch the 'arts of nature.' The Dutch constitution, revised in 1848 by Thorbecke, was based on this understanding of the natural systems as it regarded the state as a living, logically functioning, organism and governance of the country, provinces and municipalities as the vital organs of the state [5]. The farmers left the countryside and moved to the cities to improve their poor living conditions [6], causing population growth in the cities and a dependency to the countryside for the food production. The human excrements turned from fertilizers for agriculture into 'waste' that was efficiently disposed of by the sewage systems and dumped upon the surface water. In the late $19^{\text {th }}$ century, we recognize a shift in the perspective of city dwellers towards the countryside from aversion towards a 'useful' place to visit, but also to protect.

\subsubsection{Urban design based on natural systems}

At the beginning of the $20^{\text {th }}$ century, urban design concepts such as the garden city [7] and the functional city [8] tried to reconnect the connection between nature and culture. The garden city designers based their designs on the terrain (the context) by using the existing roads and trees [9], while the functional city designers ignored the existing landscape and the natural givens, as they worked according to the empty wall principle [10]. The functionalist designers did, however, use the term organic [11], by referring to the city as a biological phenomenon, an organism that developed through evolution. After WWII, the articulated city concept [12] advocated human-centred urban design by the focus on the individual level and local communities. The city became a structure of districts and neighbourhoods that formed one organic entirety that provided a place for an urban community.

\subsubsection{Distinction and diffusion between nature and the city}

As of the WWII, the distinction between nature and the city increased, driven by the articulated city concept and the agricultural policies of the state. The Green Heart became the 'food barn' of the Randstad [13] and mono-functional areas of nature and agriculture were created. In the 1970s the urban renewal projects based on centres of urban growth and concentrated deconcentration made the distinction between the city and the landscape diffused again. The agglomerations [14] were replaced by the concept of urban regions, which aimed to stimulate consumption by offering a large variety of the ideal housing typologies of the single family homes with gardens to avoid the migration out of the city [15]. 


\subsubsection{Protecting and accommodating nature}

The spatial planning policies of the 1970s focused on the preservation and reinforcement of the natural urban structures, directed at improving the living environment and disincentive policies regarding mobility. The oil crises of 1973 and 1979 supported the policies combined with the environmental movement [15]. Spatial consumption was minimized, and regulations were established to support the National Parks and rural planning by management agreements with farmers to support environmentally friendly farming methods. In the $1980 \mathrm{~s}$ the policies $[16,17]$ shifted towards the environment. The state realized that the cities could not expand within the boundaries of the compact city and the urban regions and focused on the quality of the living environment. Ecological infrastructures were introduced to connect the 'green' spaces of the countryside, supported by the European agriculture policies that also shifted towards the environmental aspects of the sector. The state aimed to solve the ecological problems by decreasing mobility through managing companies' location, good quality public transport in urban expansion areas and renewed green areas, supported by land costs grants and financial contributions.

\subsubsection{Integrating nature as a service}

The spatial policies shifted from control planning, in 1990, towards development planning [13]. The state worked together with private parties on their housing and urban development tasks under the term area development [18]. Spatial policies aimed to create space for various functions on the limited surface of the Netherlands, by strategies to strengthen the international competitiveness, promoting strong cities and vital countryside's while assuring safety. In 2007, the state aimed at flood prevention for the rivers by improving the 'spatial qualities' of the banks by creating published 'Space for the Rivers'. This transition from stemming the water to accommodating the water as a natural service is remarkable in the light of the Dutch history with water. Alongside these policy changes another perspective to the relation between nature and culture arose: that of 'nature as a service', or ecosystem services [19], in which ecological systems are beneficial for the urban environment. Business models were developed that could calculate natural services as benefits [20]. Natural services could be beneficial for human welfare and economic developments, when connected to a holistic alternative approach.

\subsection{Continuous development of new technologies}

Technological inventions of the industrial revolution replaced human labour with coal and oil, which could generate of more power.

\subsubsection{Technological inventions, science and society}

The technological findings found their application in the second half of the $19^{\text {th }}$ century by, for example, the construction of the railways, requiring exact scientific calculations, drawings and planning by the state. The introduction of prefabricated structural steel resulted in the application of mathematics combined with the standardized technical drawings, graphs and charts [5]. Maps of the country were 
drawn and the geographical measuring systems became more precise [5]. In the $19^{\text {th }}$ century planning and systematics determined science and society [5]. The insides in the systematics of nature and the ability to influence nature changed the belief system of society. The 'good, the beautiful and the true' was replaced by mechanization and organization and the ongoing struggle for power over space and time [5].

\subsubsection{Mass communication, mass production}

In the period between 1900 and 1950, technologies for mass communication and mass production were introduced. It was the first time that written and painted sources were sublimated by other sources, e.g. sound records, photography and film. In the 1930s the radio became the medium for communication, after WWII, accompanied by the television.

The innovations for the industrialized production methods and science based technologies were driven by multinational companies to benefit their product development and production process. Resulting in changes to the education system and increasing labour markets for the higher educated middle class and more attention for the social aspects of the labour market. The improvement of the employment terms and working conditions was based on the growing awareness that industrialized mass production could only work with mass consumption. The banking sector gained an important role in the development of the business, by credit loans provision and the growing demand for financial infrastructure between the international companies.

\subsubsection{Mass mobility}

The dirt roads were paved and transformed into 'artificial roads' by the state and the provinces at the end of the $19^{\text {th }}$ century. The tram allowed mass tourism to the countryside and strengthened the functional relation between the cities and the regions. The city centres became economic, cultural and social hubs, while the suburbs became the residential locations to which the residents could commute by tram or bike. The bicycle became available for a larger part of society at the end of the $19^{\text {th }}$ century. The car became the dominant means of transport, as of the second half of the $20^{\text {th }}$ century. The number of cars increased from 150 in 1900 to 2,5 million in 1970 and $3 / 4$ of the Dutch households in 2000 [21]. The main ports of Schiphol and Rotterdam became increasingly important for the Dutch economy, supported by the container revolution. Cannels were dug to increase the accessibility of the ports and speed and time became the most important factors to optimize the infrastructure and the ships. The state facilitated the construction of new roads towards the main ports, until in 1970 society opposed to this trend, because of the rising environmental awareness. The state started with attempts to decrease mobility by spatial planning, but after 15 years the growth still doubled, resulting in traffic jams, safety issues, decreasing liveability, economic damage and societal discontent.

\subsubsection{Technology and science driven}

Next to the Housing Act of 1901, several other laws, based on the technological inventions influenced the urban development [22]. The Act comprised building 
regulations concerning the improvement of housing; the possibility of expropriation to achieve urban development; and financial contributions to housing associations. Larger and expanding municipalities were obligated to establish an expansion plan in which public space was regulated. The Building Block was the most popular building typology, built by private investors, housing corporations and philanthropic urban planners. These 'enlightened' manufacturers aimed to provide their workers with adequate housing, close to their factory, in a healthy green environment to shield the workers from alcohol and crime, while creating dependencies of the workers. Modernization was the keyword to enable consistency with the increasing pace of society that required space.

In the first half of the $20^{\text {th }}$ century, three urban design concepts prevailed: monumental, garden city and functional, each with their own characteristics and visionary backgrounds. The monumental urban design concept focused on the aesthetics of the facades, behind which the layout of the houses was designed by the contractors. The discussion regarding the societal impact of this urban design focused on form and emotion versus function and rationality. The garden city concept [7] included idealistic aspects regarding the societal values for the working and middle class citizens, also referred to as the suburban lifestyle. Functional urban design [8] was based on the systematic planning of urban societal functions, grounded in analysis and scientific (demographic) research. Industrialized mass production in (public) housing projects was the result and, as they stated, the only solution to accommodate the population growth in cities [8]. The centralized city pattern evolved towards a linear city pattern with ribbon developments. The four main functions of the city (living, working, leisure and traffic) became assumptions for a new formula. In the 1950s and 1960s these formulas seemed to work well in the development of the city expansion plans.

The expansion plan for Amsterdam (1939) was based on these functional design principles combined with the garden city concept, directed at a finalized city image in 2000 . After the WWII, the plans were carried out by the state, which resulted in a large uniform urban design and a shift from intuition and imagination (garden city) based urban design towards science based spatial planning (functional city) to coop with growth. The Expansion Plan for Amsterdam was based on economic and social sciences resulting in quantitative prognoses based on demographic predictions to forecast the need for housing and facilities. This strategy was thereafter applied in the spatial planning policies of the Netherlands for decades and reached its peak in the 1960-70s.

\subsubsection{Socio-technical engineering}

After WWII, the aim of the state was to oversee the reconstruction and spatial planning. The housing and money shortage were leading to a systematically planned, central approach, based on demographic predictions (of 20 million inhabitants in 2000). The concept of bundled decentralisation seemed well suited and resulted in huge expansion areas and industrial parks. The working methods were based on the 'makeability of space,' requiring experts in spatial planning. In the 1970s new themes as: urban renewal and centres of urban growth became leading. Until 1984, water management policies were based on controlling and 
managing the risks to guaranty safety for all citizens. At the end of the 1980s, with the introduction of the National Ecological Network a better alignment between water management and spatial policies was achieved. After the major flooding in 1993 and 1995, the relation between climate change, the rising sea levels and soil subsidence was explicitly made and the traditional (technological driven) approach was abandoned and a diverse group of societal actors were involved into the process.

\subsubsection{Market driven}

Whereas in the seventies the state's focus was on housing the low income groups and providing them with public facilities, in the eighties the economic motivation became the most important driver for the spatial planning policies. The European borders were opened, in 1990, resulting to competition between European cities to attract multinational companies. The role of cities in the Dutch economy became a dominant theme [15]. Private parties were involved in public private partnerships to cooperate with the state in the spatial developments. In the 1990s the spatial policies were directed to the coherence between the separate urban areas and the state received a facilitating role in the process, providing guidelines and freedom for the other actors in the process.

\subsubsection{Technology as the solution}

Technology was seen as the solution at the beginning of the $21^{\text {st }}$ century, for example, in the mobility policies in which the state attempted to reduce the negative impacts on the natural environment by the optimization of road use by ICT innovations and electric and hybrid cars. Area development approach was expected to solve the mobility problems on a spatial scale because of the areafocused approach and the aim to develop strategies to integrate the spatial, mobility, economy and environmental aspects integrally [18].

\subsection{Increasing consumption of products and space}

The population of the Netherlands increased from 2 million in 1800, 3.1 in 1850 to 5 million in 1900. Between 1830 and 1900 an increasing number of residents lived in cities larger than 100,000 inhabitants and a decreasing number of inhabitants lived in municipalities smaller than 20,000 inhabitants [23]. The migration to the cities had economic, as well as cultural motives [24]. In the cities, life was focused on the external world rather than the internal world which was the case on the country side, were life focused to the local community [5].

\subsubsection{Power over time and space}

The German geographer Ratzel [25] described with his concept of 'Lebensraum' the urge of a society to grow, like an organism, requiring more resources and energy. This natural metaphor was used to explain the urge of society to grow and to conquer space from nature and other 'savages' (non-western societies) [5]. As described in sections 2.2.1-2.2.3, the infrastructural works supported spatial growth in the $19^{\text {th }}$ century. The spatial decisions of the state were not based on science alone, but on the area that had the fastest 'pace of life,' (known as the 
Randstad). The determination of the public interests became a selective sum on which the conclusions based on (economic) growth [5]. As society reached higher levels of wealth, more citizens were able to enjoy the country sides in the summer, travelling to their manors and pensions.

\subsubsection{Mass consumption}

At the beginning of the $20^{\text {th }}$ century, the social inequalities started to decline as the bourgeoisie realized that the working conditions in their factories had to be improved, as mass production required mass consumption. The middle class was required to purchase these consumption products. The unions supported this movement and social legislations were established to remove the worst excesses of the capitalist system of production, resulting in the first principles of the welfare state [6]. The middle class living in cities started to grow rapidly between 1900 and 1950. The Netherlands could be characterized as a conservative country these days, as the pillarization [26] wielded all kinds of conservative norms and values [27]. The ban on contraception in the Roman Catholic circles exemplifies this. In liberal and socialist groups contraception was not banned, but they were cautiously in terms of expressions too. This is one of the causes for the high birth rates in this period that resulted in a population growth from 5 million in 1900 to 10 million in $1950[21]$.

\subsubsection{Growth driven}

The cities expanded, due to the population growth; in an accelerating pace, requiring expansion plans to guide the increasing spatial consumption. Next to the hygienic arguments: 'light, air and space' other values of importance for the urban developments of this period were the broader exaltation of the working class. The urban plans aimed for cosines, comfort, security and community building, referred to as the anthropological aspects of urban design. Living in the suburbs was no longer restricted to the upper class of society; the middle class became able to move to the periphery too. This new middle class reflected the socio-cultural behaviour of the upper-class. They desired a two generational family too, in which the man was the provider while the woman took the responsibility for household chores and raising the children. This movement combined with the state policies resulted in consistent large-scale housing developments.

Housing shortage was the main driver of the post WWII spatial planning, which required a systematically planned central approach that allowed for the addition of 480000 houses between 1945 and 1955 [21]. The density was set for the residential zones supplemented with the housing-related functions as churches, schools, shops, parks, public gardens, sports and playgrounds (see the articulated city concept, 2.1.2). The housing stock increased from 1 million houses to 1,8 million houses in 1930, 3,8 million in 1970, 5,3 in 1985, 6,6 in 2000 and 7,3 in 2012 [21].

Since the 50s, especially in the 60 s the Netherlands experienced a period of continuous economic growth, the average income increased by $44 \%$ in 1960 and $200 \%$ in 1970 [21]. Consumption freedom was seen as the cornerstone of state policy [28] resulting in stimulating policies for car use and the suburban lifestyle [15]. 


\subsubsection{Controlling growth}

The various national spatial planning documents of the state that were published until the 1970s prescribed different approaches to direct growth within the urban environment; from the centres of growth to the facilitation of growth by the focus on bundled decentralisation and the concept of urban regions. As of the 1970s, controlling growth seemed crucial combined with regulations to protect the natural environment. The concept of the coherent large-scale urban structures was abandoned and replaced by small scale developments. The working methods changed into a more democratic spatial planning with citizens' involvement. The urban renewal policies resulted in preserving the vibrant historic city centres and the spatial planning policies involved environmental criteria and policies to decrease mobility as described in 2.1.4 and 2.2.3.

\subsubsection{Economic growth}

As off the 1980s the spatial policies were influenced by the internationalisation and the economic motives became leading for the spatial planning regulations [17] the compact city ideal was abandoned, and the state policies shifted from public housing towards the international economic market. Business districts received a prominent location within the city and office parks were added to the existing cities to facilitate the demand for working space, resulting in mono-functional areas. The demand for housing was still rising, and spatial planning became a tool to decrease the ecological problems and mobility by location policies and the focus on good quality public transport in urban expansion areas.

\subsubsection{Accommodating growth}

After 2000, the controlling approach to national spatial planning was abandoned. The state was challenged to integrate the societal changes of the service economy and the empowerment of citizens into their spatial policy. The Spatial Planning Act of 2008 replaced the municipal structure plans and the provincial rural spatial plans and the National Spatial Planning Key Decisions by structural concepts. All three governmental levels have to make structural concepts for the areas of their responsibilities to provide space for growth.

\section{Recurring patterns}

\subsection{Migration to the city centre and back to the suburbs}

We have recognised that the urge to move towards the city centre and back to the suburbs again is a recurring pattern influenced by technological inventions (i.e. train, tram and car), societal changes (i.e. the arising middle class), and the aim to connect to the natural environment, resulting, together with the increasing population, in the increasing spatial consumption. The state tried to control this spatial consumption with the introduction of concepts as the compact city and by the aim to reduce mobility. The influence of the international economic market hindered to continue these policies, as the market supported this recurring pattern by responding to the needs of certain societal classes who were able to afford their 
ideal 'green' living environment. This has resulted in supply-driven urban developments of offices, houses, and industrial areas of which some of them are already abandoned because of the lack of flexibility.

Our cities have major differences in spatial experience; from the historic city centres with cannels and historic architecture to the large scale concrete housing and office buildings of mid- $20^{\text {th }}$ century, to the VINEX locations were modern, contemporary architecture is combined with neo-traditional styles.

\subsection{Separation and integration of different functions within the city}

The functions within the cities diversified (with the farmers moving to the cities and the factories attracted them), clustered (monumental and garden city urban design concepts) to be completely separated (functional city concept). The state was supporting the functional city concept in their planning policies, and, therefore, was supporting the function separation within the cities. The real estate market continued this trend in the eighties, resulting in the mono-functional office areas. Driven by the economic crises and the 'new way of working' [29] we recognise a countertrend that is stimulating the functions to merge again, supported by the civil society movements which are exploring other societal relations and working methods. Function integration still has its practical challenges that have to be overcome, for example, the aging population who is hindered by the layout of the family homes of the centres of urban growth [30].

The supply-driven prediction methods for facilities are outdated and not able to be adapted to the current societal challenges.

\subsection{Spatial planning by the state, the market or civil society}

The role of the state, the market and civil society in the spatial planning system changed over the past 200 years. Started by a market driven system in the $19^{\text {th }}$ century in which the state was primarily concerned to protect the public interest and reluctant to obtain a monopoly position. Followed by almost a century of state controlled spatial planning in which we recognised various small adaptions in the divisions of responsibilities with regard to the local governments. Subsequent by a period in which the market gained influence again in the spatial developments, which is currently halted because of the economic crisis. Some still think this could come back again, while other focus on smaller scale area developments in which the state and de local governments facilitate the area development process initiated and financed by market and civil society parties. Municipalities struggle with their new facilitating role as it requires a change in their municipal structure, culture, and practice [31]. Parallel to these area development new style' we also recognise smaller scaled bottom-up initiatives from civil society that are aiming to develop spatial areas without the involvement of the state. 


\subsection{Lessons for a beneficial approach for spatial planning}

An alternative approach could be beneficial for natural systems as well as for society by the focus on a demand-driven flexible approach and a (participatory) process that involves actors from the state, market and civil society as well as actors who can represent nature as a 'stakeholder' [32]. Spatial areas could be redeveloped to support societal growth, by integrating diverse social infrastructures as well as by the focus on citizen empowerment in the process.

Beneficial growth could be supported through the focus on ecosystem services and societal services while linking them to economic growth. We could heal the natural environment by Beneficial Area Development when we distinguish between natural biological systems that create benefits (biological nutrients) for nature and society, and technological systems that create benefits (services) for society. These biological and technological systems, or spheres, need to be kept in separate environments to be able to create these benefits [33].

The redevelopment of these beneficial areas is based on long term vision, created by multiple stakeholders that are carefully selected for their ability to think beyond the established approaches. This selective group of 'frontrunners' [34], from different domains will be challenged to integrate the different perspectives (environmental, societal, and economic) into one beneficial vision. This process could be supported by the technological innovations (e.g. social media and open source data) because it allows more stakeholders to contribute to the process through interactive, bottom-up initiatives. However, technology is not seen as the solution for spatial developments, rather as a supporting factor for the process as well as for the technological systems that could be upcycled [35] over time.

This demand-driven flexible approach, based on the integration of the diverse functions within the cities, would be able to coop with uncertainties, instead of top-down restricting policies by the state. New roles and working methods will need to be explored in which citizens and market parties are challenged to be involved in the process, implementation, usage and redevelopment phases of these Beneficial Area Developments.

\section{Conclusion}

We started our paper by analysing the past 200 years of spatial planning in the Netherlands. This resulted into insides on how the system was optimized, based on technological developments and demographic and economic growth, without integrating nature and society. Hereafter we distilled the recurring patterns that influenced the autonomous developments and combined those lessons into the alternative approach for Beneficial Area Development. To conclude with suggestions regarding the role of technologies, the state, market and/or civil society could support the process of Beneficial Area Development and herby create environmental and societal benefits through economic developments. 


\section{References}

[1] WCED. Our Common Future (The Brundtland Report). United Nations World Commission on Environment and Development 1987.

[2] United Nations. Economic Commission for Europe. Major trends characterizing human settlements development in the ECE region 1998; 108.

[3] Commission of the European Communities. Green Paper on the Urban Environment. 1990.

[4] Rotmans J, Loorbach D. Complexity and transition management. J. Ind. Ecol. 2009; 13: 184-96.

[5] van der Woud A. Een nieuwe wereld, het ontstaan van het moderne Nederland. Amsterdam: Uitgeverij Bert Bakker, 2006.

[6] Doevendans K. Reader Stedenbouw. Eindhoven: Eindhoven University of Technology, 2007.

[7] Ebenezer H. Garden cities of to-morrow. London: Swan Sonnenschein \& Co, 1902.

[8] Mumford EP. The CIAM discourse on urbanism, 1928-1960: MIT Press, 2002.

[9] Castex J, Depaule J, Panerai P, Engel H, Hoffmans J, Kuitenbrouwer R. De rationele stad: van bouwblok tot wooneenheid. Nijmegen: Sun, 2003.

[10] Benevolo L. History of modern architecture. London: Routledge, 1971.

[11] Sert JL. Can Our Cities Survive? An ABC of urban problems, their analysis, their solutions. Cambridge, MA: Harvard University Press, 1947.

[12] Bos A, Oud P. De stad der toekomst, De toekomst der stad. Rotterdam: Voorhoeve, 1946.

[13] Minnesma M, Rotmans J. Systeem Ruimtelijke Orde - vanuit transitieperspectief 2007.

[14] Mera K. On the urban agglomeration and economic efficiency. Economic Development and Cultural Change 1973: 309-24.

[15] [Zonneveld W. Conceptvorming in de ruimtelijke planning: encyclopedie van planconcepten 1991.

[16] Ministerie van Volksgezondheid en Milieuhygiene. Directoraat-Generaal Milieuhygiëne 1982.

[17] Ministerie van Volkshuisvesting Ruimtelijke Ordening en Milieu. Vierde Nota over de Ruimtelijke Ordening. Sdu, Den Haag 1988.

[18] VROM. Brief van de minister van volkshuisvesting, ruimtelijke ordening en milieubeheer 2004; 2012.

[19] Haase D, Larondelle N, Andersson E. et al. A quantitative review of urban ecosystem service assessments: Concepts, models, and implementation. Ambio 2014; 43: 413-33.

[20] TEEB - The Economics of Ecosystems and Biodiversity. TEEB Manual for Cities: Ecosystem Services in Urban Management. 2011: 18.

[21] CBS/Satline. Historische reeksen: Nederland van 1800 tot nu 2014; 2014. 
[22] Smook R. Binnensteden veranderen: atlas van het ruimtelijk veranderingsproces van Nederlandse binnensteden in de laatste anderhalve eeuw. Zutphen: De Walburg Pers, 1984.

[23] Postmus J. Een onderzoek naar omvang en aard van de bevolkingsconcentratie in Nederland sedert 1830. Amsterdam: Swets en Zeitlinger, 1928.

[24] Verrijn Stuart C. Inleiding tot de beoefening der statistiek. Haarlem: 1917.

[25] Smith WD. Friedrich Ratzel and the origins of Lebensraum. German Studies Review 1980: 51-68.

[26] Lijphart A. The politics of accommodation: Pluralism and democracy in the Netherlands. California: University of California Press, 1968.

[27] Jong L. Het koninkrijk der Nederlanden in de Tweede Wereldoorlog Staatsdrukkerij-en Uitgeverijbedrijf, 1979.

[28] Minister van Economische Zaken, den Uyl JM, Bakker JA. Nota inzaken groeien structuur van onze economie 1966.

[29] Doorn M, Wit M. Het Nieuwe werken. Nieuwerwets 2009: 11-41.

[30] Centraal Bureau voor de Statistiek, Planbureau voor de Leefomgeving. Regionale prognose 2013-2040. 2013.

[31] Rotmans J. Gebiedsontwikkeling 3.0: crisis als kans voor een wezenlijk andere aanpak 2011.

[32] Woodward DG. Is the natural environment a stakeholder? Of course it is (no matter what the Utilitarians might say)! Critical Perspectives on Accounting Conference. New York, USA: Baruch College: City University of New York, 2002.

[33] Braungart M, McDonough W, Bollinger A. Cradle-to-cradle design: creating healthy emissions - a strategy for eco-effective product and system design. J. Clean. Prod. 2007; 15: 1337-48.

[34] Loorbach D. Transition management for sustainable development: $A$ prescriptive, complexity-based governance framework. Governance 2010; 23: 161-83.

[35] McDonough W, Braungart M. The Upcycle: Beyond SustainabilityDesigning for Abundance: North Point Press, 2013. 